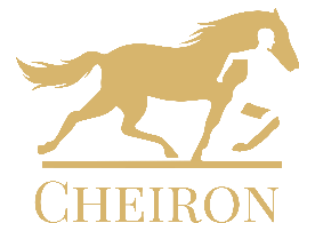

Cheiron: The International Journal of Equine and Equestrian History

Vol. 1, Issue 1/2021

(C) The Authors 2021

Available online at

http://trivent-publishing.eu/

\title{
The Horse Behind the Text: Animal Agency in Early Medieval Historiography
}

\author{
Marieke Röben
}

\begin{abstract}
Early medieval authors frequently used horses as narrative devices. Therefore, when working with bistoriographical sources, one is confronted with a vital question: how can we reconstruct the horses' agency without knowing whether their depiction is a mere narrative device? Combining praxeological approaches with the analysis of narrative structures, this paper offers a glance "beyond the text." It shows how analysing the underlying knowledge of the medieval reader contributes to reconstructing a contemporary image of early medieval horses and their (perceived) agency in human society and thereby develops a new perspective for the future of historical buman-animal studies.
\end{abstract}

\section{Keywords}

Animal agency; early Middle Ages; historiography; horse history; human-animal studies; narratology; praxeology.

DOI: 10.22618/TP.Cheiron.20211.1.233003

CHEIRON is published by Trivent Publishing

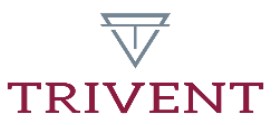

This is an Open Access article distributed in accordance with the Creative Commons Attribution Non Commercial (CC$B Y-N C$-ND 4.0) license, which permits others to copy or share the article, provided original work is properly cited and that this is not done for commercial purposes. Users may not remix, transform, or build upon the material and may not distribute the modified material (bttp:/ / creativecommons.org/ licenses/by-nc/4.0/) 


\title{
The Horse Behind the Text: Animal Agency in Early Medieval Historiography
}

\author{
Marieke Röben ${ }^{1}$
}

\begin{abstract}
Early medieval authors frequently used horses as narrative devices. Therefore, when working with historiographical sources, one is confronted with a vital question: how can we reconstruct the horses' agency without knowing whether their depiction is a mere narrative device? Combining praxeological approaches with the analysis of narrative structures, this paper offers a glance "beyond the text." It shows how analysing the underlying knowledge of the medieval reader contributes to reconstructing a contemporary image of early medieval horses and their (perceived) agency in human society and thereby develops a new perspective for the future of historical human-animal studies.
\end{abstract}

\section{Keywords}

Animal agency; early Middle Ages; historiography; horse history; human-animal studies; narratology; praxeology

\section{Introduction: The problem with horses in early medieval historiography}

Everywhere and at all times, our world has been inhabited not only by us humans, but predominantly by animals. Our world, therefore, is necessarily shaped by both us and the animals that live with us or alongside us. For the early Middle Ages, horses were one very important group of these animals. Without them, the system of transportation, the economy, and the military would have evolved very differently, and the world would have been a different place. Acknowledging this impact that horses had on human society means granting them some sort of power - some sort of agency. But what did this agency look like and how was it exerted?

Nowadays, there is a vivid discourse surrounding animals, their consciousness, their behaviour, and so on. Dealing with the early Middle Ages, however, we are facing a more anthropocentric view. In early medieval historiography, horses are mostly presented as objects or creatures controlled by humans - their agency is hardly ever taken into account. Moreover, the authors frequently used horses to style their narrations - underlining the status of a character by describing their noble horse, emphasising the gravity of a situation by depicting the horses bucking, and such like - which makes it virtually impossible to judge whether a depiction is historically accurate or not, making it even harder to find out what kind of historical agency horses exerted.

However, neither does the fact that medieval authors styled their chronicles according to literary and historiographic conventions make the reconstruction of horse agency from them impossible, nor does the exclusion of horse agency from the narration prove that horses did not actually exert it. In order to find out how horses influenced the human world in the early

\footnotetext{
${ }^{1}$ Universität Hamburg (Medieval History), Germany.
} 
Middle Ages, we need to challenge the sources with a more subtle approach - one that reads between the lines and takes a look at what is hidden behind the text.

In this paper, I wish to present a methodological approach to early medieval historiography that will serve to find the horse agency that is not directly described in it. After presenting some thoughts on the nature of animal agency as a whole, moving away from an anthropocentric view and instead focussing on the animal, this article will show how the depictions of horses - be they stylistically elaborate, dramatic descriptions or short, hardly noticeable mentions - can be read against the grain to reach an integral view of historical horse agency.

In order to understand the depictions of agency we find in the sources, we need to be aware of the diverse roles horses played in the early medieval world. Their importance extends far beyond their role as riding animals - they were, for a significant part of the population (and certainly for the authors writing historiography), basically omnipresent. Unlike today, where - at least in western Europe, where the sources used for this article originated - they almost exclusively appear in sporting activities, in early medieval society, they played a lot of different roles and, thus, had loads of possibilities of shaping the human ways of life.

Horses in the early Middle Ages were, to cut it short, providers of physical strength that enabled diverse means of transportation for humans and goods as well as assisting in other strenuous physical activities. They were employed as beasts of burden to carry heavy weights, but also as draft animals and in some parts also for ploughing. ${ }^{2}$ As mounts, they were employed for transportation and sometimes also as riding animals for mounted troops. ${ }^{3}$ Being expensive to keep and feed, they were very valuable, which is why they were also considered to be status symbols, and horses with different qualities were selected for different purposes. ${ }^{4}$

In all of these fields, the horses' cooperation enabled humans to reach their goals, as is explained in the next section. The omnipresence of horses in the early medieval human world is both a curse - an issue that is discussed in section III - and a blessing because it shows us just how many different roles horses took on and, accordingly, the ways in which they could influence humans. This leaves a lot of room for speculations about horse agency: How did horses act and which chances of changing their surroundings did they have? For this paper, I will focus on the horse as a riding animal, as this is the function in which they are most often mentioned in the historiographical sources, and show in which way these depictions represent animal agency. But before I turn to the sources, we must challenge the methodological basis for this endeavour, and ask: what actually is horse agency?

\footnotetext{
2 Although oxen remained the preferred animal for agricultural work due to their lower cost in maintaining, horses also were used for different labours. Joyce E. Salisbury, The Beast Within. Animals in the Middle Ages (London: Routledge, 2010), 16-17. For example, we find the mention of horses or mules drawing the parts of a ship in the Life of Emperor Louis. Anonymus, "Vita Hludowici imperatoris," in Scriptores rerum Sangallensium. Annales, chronica et historia aevi Carolini, ed. Georg Heinrich Pertz (Hannover: Hahn, 1829), 614. A detailed analysis of horses as draft animals in imagery can be found in Gail Brownrigg, "Medieval Horse Harness. The Evidence of the Images," in The Horse in Premodern European Culture, ed. Anastasija Ropa and Timothy Dawson. Studies in medieval and early modern culture 70 (Berlin/Boston: DeGruyter, 2019), 55-67.

${ }^{3}$ Bernard S. Bachrach, "Animals and warfare in early medieval Europe," in L'uomo di fronte al mondo animale nell'alto Medioevo, ed. Centro italiano di studi sull'alto medioevo. Settimane di studio del Centro Italiano di Studi sull'Alto Medioevo 31 (Spoleto: Presso la Sede del Centro, 1984), 730-735.

${ }^{4}$ Pascale Bourgain, "Pratique de l'équitation au Moyen Âge d'après les textes littéraires," In Situ 18 (2012), https://journals.openedition.org/insitu/9721 (accessed February 24, 2021).
} 


\section{Animal Agency: Some thoughts on a complex concept}

Considering all the different roles horses played and the multitude of aspects of early medieval life that their labour and cooperation made possible, there is no arguing if horses had some sort of impact, agency or power over humans: it is a fact that they did. But looking at those passages of historiography that feature horses, it is not always obvious what that power entailed and how it was exerted. How horse agency was perceived, in which contexts it influenced early medieval society and how it is reflected in historiographical texts can only be found out by looking at the sources - and beyond them.

The question of if and how animals act and have an impact on the human world has been discussed many times, and many different notions have been brought forward. ${ }^{5}$ The following sections will focus on some select thoughts and conceptions surrounding this complex issue that can help in finding horse agency "behind" early medieval historiography.

\section{A. Horses and Agency}

When it comes to animal agency, many different ideas have been discussed that show fundamental contra-distinctions. Firstly, some of them view humans and animals as two fundamentally different beings and assume a dichotomy between the two groups, whilst others understand "being human" and "being animal" as two points of a continuum, which is often marked by the usage of the terms "human animals" and "nonhuman animals." Secondly, the concept of agency per se can also be viewed differently. It can be defined as the power to alter situations or conditions by employing one's free will, meaning animals act consciously. ${ }^{6}$ This, for example, has been done by Shelly R. Scott, who in her article "The Racehorse as Protagonist: Agency, Independence, and Improvisation" examines the agency of (race)horses and offers a definition of agency as "an intentional exertion of power, involving more than merely action or reaction." 7 This definition, however, is based on an anthropocentric sociological view of agency and cannot meet the demands of animal history, as it draws a line between instinct and free will that does not do justice to the complexity of animal behaviour. The separation between the two is one that can only be done by applying human standards. If a horse is startled, bucks, and runs away, who is to decide whether it did so by instinct (as a mere reaction) or free will (as agency)?

Scott also argues that animals under human command do not exercise agency and limits the concept mostly to deviation and improvisation. ${ }^{8}$ Following this definition, a horse carrying its rider across a bridge would pose no case of animal agency, as the horse simply reacts to the rider giving the correct commands. This radically limits the spectrum of animal

\footnotetext{
${ }^{5}$ A complete overview of the subject would extend beyond the volume of this article. Therefore, a reference to two of the latest works on the matter must suffice at this point: An overview over different approaches to human-animal history can be found in The Routledge Companion to Animal-Human History, ed. Hilda Kean, Philip Howell (Boca Raton, FL: Routledge 2018). A more recent publication, Outside the anthropological machine. Crossing the buman-animal divide and other exit strategies, ed. Chiara Mengozzi (London/New York: Routledge Taylor \& Francis Group, 2021), focusses on interspecies borders and how to deal with them in human-animal history.

${ }^{6}$ Sarah E. McFarland and Ryan Hediger, "Approaching the agency of other animals. An introduction," in Animals and Agency. An Interdisciplinary Exploration, ed. Sarah E. McFarland and Ryan Hediger. Human animal studies 8 (Leiden/Boston: Brill 2009), 1-20, give a helpful overview of the different approaches. 7 Shelly R. Scott, "The Racehorse as Protagonist. Agency, Independence, and Improvisation," in Animals and Agency. An Interdisciplinary Exploration, ed. Sarah E. McFarland and Ryan Hediger. Human animal studies 8 (Leiden/Boston: Brill 2009), 47.

8 Scott, "The Racehorse as Protagonist," 47-48.
} 
agency, as it leaves no room for the agency horses execute by not improvising, not resisting. If agency could only be understood as intentional deviation from the expected behaviour, then we would have to argue that the horses keeping the transport system of the early medieval world going by carrying their riders as commanded or supporting the agriculture by pulling carts without proper resistance did so without any form of agency. But this draws only part of the picture, which is why a different approach is more fruitful.

The understanding of agency can move away from the idea of intentionality and, instead, focus on the idea of social participation as performative actions. ${ }^{9}$ This approach is the most appropriate one to grasp the impact that horses had on the early medieval human world. Many situations in which humans depended on horses - having them pull a cart or carry a knight into battle - can only be fully acknowledged if we, instead of looking for traces of free will ("Did the horse decide to carry the knight into battle?"), look for the impact the horses had by acting and how this had an impact on the world ("The horse carried the knight compliantly. Was this essential for the knight and, thus, did the horse make the knight's job of fighting possible?"). Agency must, therefore, be understood as the power of altering reality consciously or subconsciously, intentionally or unintentionally. In addition, comprehending actions as a more bodily process offers more possibilities of understanding how nonhuman animals interact with and impact human animals, which is why the second part of this chapter will be dealing with the concept of praxeology. This first section, however, will focus generally on the concept of animal agency in history and the question of how to deal with it.

In his essay "Animals, agency, and history," Philip Howell establishes a system of categories that help understand animal agency in historical accounts. He distinguishes between ascribed animal agencies, agonistic animal agencies and assembled agencies (the alliteration certainly being purely accidental) ${ }^{10}$ which - when applied to the sources - can produce very different views of animal agency in history.

The concept of assembled agencies describes the agencies of human and nonhuman animals as a reciprocal concept in which the agencies of all involved parties coexist and cooperate. ${ }^{11}$ In this view, neither the horse nor the rider are solely responsible for the act of riding. Rather, the rider executes their agency in giving the adequate commands and the horse executes its own agency in accepting these offers ${ }^{12}$ - much like a couple dancing where one party may take the lead, but the dance will only work out if both partners cooperate. Scott's description of the relationship between the jockey and the horse illustrates this correlation:

the jockey must be able to adjust to the horse in order to produce the best ride. In other words, the job of the jockey is to respond to the horse's actions. Thus, the agency exerted by the rider depends on the agency exerted by the thoroughbred. ${ }^{13}$

In this context, it must also be kept in mind that there is an imbalance of power between the rider and the horse. Acknowledging the notion that humans and other species essentially

\footnotetext{
${ }^{9}$ Gesine Krüger, Aline Steinbrecher and Clemens Wischermann, "Animate History. Zugänge und Konzepte einer Geschichte zwischen Menschen und Tieren," in Tiere und Geschichte. Konturen einer Animate History, ed. Gesine Krüger, Aline Steinbrecher and Clemens Wischermann (Stuttgart: Franz Steiner Verlag 2014), 31.

${ }^{10}$ Philip Howell, "Animals, agency, and history," in The Routledge Companion to Animal-Human History, ed. Hilda Kean and Philip Howell (Boca Raton, FL: Routledge 2018), 197-221.

${ }^{11}$ Howell, "Animals, agency, and history," 207-209.

12 The term "offers" is taken from the art of acting, as explained by Scott, "The Racehorse as Protagonist," 59.

${ }^{13}$ Scott, "The Racehorse as Protagonist," 54.
} 
work together, Howell remarks that "agency can in no wise be equated with autonomy" and that "dependency and agency are not exclusive." 14 The horse may - from our point of view - be in the subordinate position, but that does not mean that it does not have the power to work its own agency. This view of human-animal interaction draws the focus away from the animals' role as the humans' helpers or tools and towards the idea of a social construct including both human and nonhuman animals exercising their respective agency. Humans, therefore, are no longer the (only) centre of attention.

This is unlike the approaches dealing with agonistic animal agencies, which mainly focus on animals acting against humans, similar to what we have already encountered in Scott's idea of agency as improvisation. This notion reads all animal actions as part of an anthropomorphic system and in relation to human rules. The animal is automatically sorted into a system of values designed to fit the humans' needs and all animal action is interpreted with regard to human society. ${ }^{15}$ If a horse bucks and its rider falls off, this may be seen as an act of agency which is directed against the human understanding of "good" animal behaviour. The problem with this notion is, as I have explained above, that it obstructs the view on animal agency as a whole (for example the agency used to not throw off the rider) and reciprocal effects between human and animal agency (assembled agencies) and is therefore to be handled with care.

However, the agonistic view of animal agency is still needed when working with early medieval sources, as all early medieval depictions of animals are shaped by an anthropocentric world view. The early medieval world perceived animals differently from the way we do today. Drawing on the Christian belief that humans are the crown of creation, relational concepts of human and nonhuman animals would seem unreasonable. ${ }^{16}$ As Augustine of Hippo, one of the theologians with the biggest impact on the early medieval world view, wrote:

quod ipse homo a veteribus sapientibus ita definitus est: Homo est animal rationale mortale. ... Uno verbo a bestiis, quod rationale, alio a divinis separatur, quod mortale dicitur; illud igitur nisi tenuerit, bestia erit, hinc nisi se averterit, divina non erit. ${ }^{17}$

[that ancient philosophers defined man as an animal both rational and mortal. ... The term "rational" sets him aside from the beasts, and the term "mortal" from God. Should he lose rationality, he would be no more than a beast, and unless he ceased to be such, he could not be divinized.] ${ }^{18}$

Here, the animal is the ultimate counterpart to humans: instinctive and improper. We also find early medieval theological writings that, in dealing with human morality, name animals as the (negative) counterpart to human virtuousness. Jonas of Orléans - an influential ninthcentury Frankish bishop - even used biblical passages referring specifically to horses and mules as bad examples in his De institutione laicali - a text that was designed to teach Christians how to live a good Christian life:

Ait et psalmographus: Nolite fieri sicut equus et mulus in quibus non est intellectus.

Item: Homo cum in honore esset non intellexit, conparatus est iumentis insipientibus et similis factus est illis. In libro quoque Tobi: Hi namque, inquit, qui coningium ita

\footnotetext{
${ }^{14}$ Howell, "Animals, agency, and history," 208.

${ }^{15}$ Howell, "Animals, agency, and history," 204-207.

${ }^{16}$ Detailed problematisation of this point can be found in Salisbury, The Beast Within.

17 Aurelius Augustinus, "De Ordine," in Contra Academicos, De beata vita, De ordine, ed. Therese Fuhrer and Simone Adam. Bibliotheca scriptorum Graecorum et Romanorum Teubneriana (Berlin/Boston: De Gruyter, 2017), 165-166.

18 Aurelius Augustinus, De Ordine, trans. Silvano Borruso (South Bend, Indiana: St. Augustine's Press, 2007), 93.
} 
suscipiunt ut Deum a sua mente excludant et suae libidini ita nacent sicut equus et mulus, habet potestatem daemon super eos.

His ergo et huiuscemodi diuinae Scripturae innumeris testimoniis tantae inpudentiae adsertores conuicti, intelligant quod membris genitalibus a Deo bono creatis non liceat ad uniuscuiusque libitum sed ad ea pro quibus ordinabiliter a Deo instituta sunt, secundum eius uoluntatem, tempore et ordine suo uti.

[Even the psalmist says: Do not be like the horse or the mule, that are without comprehension. And: Man when he was with honour did not understand: he is conditioned like the unwise beasts of burden and made like them. And in the book of Tobias: Those, namely, he says, who enter marriage in excluding God from their minds and are free to follow their lust like horse and mule, are under the power of the demon.

The asserters of such shamelessness will, convinced by these particular and numerous such testimonies of the Holy Scripture, understand that it is not desirable to use the genitals that were created by the good God as it pleases each one, but to do what they were properly created for by God, following his will, time and order.] ${ }^{19}$

These two early medieval texts perceive animals only in relation to anthropocentric standards - and, in the images at hand, never reaching the humans' benchmark. Even if these texts are theological sources and cannot pose as the generally accepted truths of the early Middle Ages, when working with different concepts of animal agency, the concept of agonistic animal agencies might be especially useful to understand how early medieval writers thought and thus help in reaching a comprehensive picture of horse agency in early medieval times. ${ }^{20}$

This brings us to the last category Howell describes: that of ascribed animal agencies. It sets out a more general concept of the history of ideas and refers to the power or agency that the people of the time period in question ascribed to animals. This concept overlaps with the other two ideas: even when analysing the historical agency of animals, we still need to keep an eye on the question which agencies were ascribed to those animals by their contemporaries ${ }^{21}$ - meaning we should ask ourselves, "Which forms of agency did the horses exert? And which forms of agency are actually portrayed as such and were thought of by the authors?"

Summing up his analysis of these three notions of animal agency, Howell notes that "these approaches are often interrelated," 22 and he also concludes that research points to "a relational conception of agency that is far more inclusive, and at the same time, far more demanding of us as historians." 23 Other historians have also correctly noted that,

Agency wird in diesen Diskussionen weit gefasst und es wird gezeigt, dass Tiere durchaus eine Wirkungsmacht hatten, denn ihre Anwesenheit und ihre Tätigkeiten waren sozial und kulturell prägend. ... Denn genauso wenig, wie

\footnotetext{
${ }_{19}$ Jonas d'Orléans, Instruction des Lä̈cs. Tome 1 (Livres I-II,16), ed. and trans. Odile Dubreucq. Sources Chrétiennes 549 (Paris: Les Éditions du Cerf, 2012), 391-392. Translation my own.

20 These two sources are only examples serving to illustrate the early medieval world view. Of course, early medieval theology could provide a more nuanced picture. Going into detail about theological understandings of humans and animals would, however, extend beyond the focus of this paper, which is historiography.

${ }^{21}$ Howell, "Animals, agency, and history," 203-204.

22 Ibidem," 210.

23 Ibidem.
} 
es eine losgelöste Geschichte der Tiere gibt, gibt es auch keine losgelöste Geschichte der Menschen[.]

[Agency, in these discussions, is broadly phrased and it is being shown that animals by all means had potency, as their presence and their activities were socially and culturally formative. ... For just as there is no detached history of animals, there is no detached history of humans.] $]^{24}$

Accounts of horses in early medieval historiography, therefore, pose the challenge of determining which agencies were ascribed to horses in the early medieval period, how they were perceived in relation to humans, and which agencies may have existed that were not named by contemporary authors at the same time. In order to address this last question, praxeological approaches can be included in the analysis of horse depictions.

\section{B. Horses and Practices}

The field of praxeology is a large one, dealing with many diverse fields and subjects, which is why, for the purposes of this article, a short introduction of those elements relevant to the question of animal agency must suffice.

Generally speaking, a praxeological approach grasps (social) interaction not as a chain of intentional, singular actions, but as a network of (sometimes bodily, sometimes spoken) practices which can be defined as "open-ended, spatially-temporally dispersed nexus of doings and sayings." 25 These practices are not limited to human action but can also be found in elements that are not rational - or not even living:

Gesellschaft wird in praxeologischer Lesart weder als das Produkt wirkmächtiger sozialer Strukturen, Funktionsweisen und Systeme verstanden noch als das Zusammenwirken kognitiv gesteuerter Einzelhandlungen und interessen, Ziele und Strategien, die in ihrer Summe als kollektives übersubjektives Produkt bestimmte Ressourcenverteilungen, Machtkonstellationen und Hegemonien ergeben. Das Soziale wird vielmehr als durch soziale Praktiken hervorgebracht konzeptualisiert, als das praktische Zusammenspiel sehr unterschiedlicher Akteure - Menschen, Körper, Artefakte, Dinge, Diskurse.

In a praxeological reading, society is understood neither as the product of efficacious social structures, operating principles, and systems, nor as the interaction of cognitively controlled, individual actions and interests, aims and strategies that in sum - as a collective, supra-subjective product - make up specific distributions of resources, constellations of power and hegemonies. The social is, rather, conceptualised as being created by social practices; as the practical interplay of very diverse actors - humans, bodies, artefacts, things, discourses.] ${ }^{26}$

\footnotetext{
${ }^{24}$ Silke Bellanger, Katja Hürlimann and Aline Steinbrecher, "Tiere - eine andere Geschichte,“ Traverse 15: 3 (2008): S. 9. Translation my own.

${ }^{25}$ Theodore Schatzki, "A Primer on Practices," in Practice-Based Education. Perspectives and Strategies, ed. Joy Higgs et al. Practice, education, work and society 6 (Rotterdam/Boston/Taipei: Sense Publishers, 2012), 14.

${ }^{26}$ Dagmar Freist, "1.4 Historische Praxeologie als Mikro-Historie," in Praktiken der Früben Neuzeit. Akteure - Handlungen - Artefakte, ed. Arndt Brendecke. Frühneuzeit-Impulse 3 (Köln/Weimar/Wien: Böhlau, 2015), 62. Translation my own.
} 
The core of influence on one's environment, in praxeological understanding, is the exertion of practices which are part of a collective understanding of appropriate ways to do things. From a sociological perspective, this means that the subject - now being secondary to the practices established among social groups - develops an understanding (a knowing bow) of what can or cannot be done. ${ }^{27}$ Naturally, this concept needs adjustment when it comes to animals, as their social structures work differently from humans', and early medieval historiography, which is centred on humans, simply does not provide the material to properly analyse inter-animal relations.

However, in the case of horse agency in historiographical texts, we work only with those instances where horses act in correlation to humans. And we can safely assume that when we read about a trained riding horse, this horse knows which behaviour is expected of it - maybe not in a conscious way, but in a conditioned, trained way. The horses, therefore, act in a certain way to either fulfil the expectations of humans or act against what is expected - making them deviant. Both deviation and obedience show horse agency and both are performed by the horse exerting certain (bodily) practices.

With recourse to the horse-jockey example by Scott, quoted above, this could be applied as follows: both the horse and the jockey use their body movements to perform the act of riding. The horse aligns its movements to the reigns and weight of the rider, the rider levels their movement with the rhythm of the horse's steps. At any given time during the riding, both the jockey or the horse could choose to leave the situation: by altering their bodily movements (ceasing to perform the corresponding practice), they would break up the connection between them and the act of riding would stop.

This approach does not need the horse to make conscious decisions and, thus, does not lead to an anthropomorphic interpretation of animal behaviour, that would sort the horse's actions into the categories of intention and instinct that only reflect human understanding of animals but not the animal behaviour itself. The praxeological approach allows us as historians to acknowledge how the bodily presence of horses influenced and shaped the human world, without reducing their impact to mere conscious expressions of free will (of whichever disposition).

Having now looked into the theoretical possibilities of grasping horse agency, we can finally turn to our sources to try and reconstruct historical animal agency from them. Like any other source group, they pose individual problems that need to be addressed.

\section{Horses as narrative devices: Agency and narrative structures}

Historiographical texts mention horses frequently and in many different contexts, using them for their storytelling purposes in different ways. Historiography is always written about human history, making the horse but an auxiliary element that serves certain purposes. Historians working with horses in historiography, therefore, need to be aware of the ways in which horses are employed in these texts.

As Isidor of Seville tells us, "A history (bistoria) is a narration of deeds accomplished; through it what occurred in the past is sorted out." 28 Now, as explained in the beginning, horses were part of everyday life in the early Middle Ages, which also means that there was usually no need to mention them in historiography: The early medieval audience would know which importance horses had and would not need to be reminded of them in every situation.

\footnotetext{
${ }^{27}$ Freist, "Historische Praxeologie," 62-63; Thomas Alkemeyer, Gunilla Budde and Dagmar Freist, "Einleitung," in Selbst-Bildungen. Soziale und kulturelle Praktiken der Subjektivierung, ed. Thomas Alkemeyer, Gunilla Budde and Dagmar Freist. Praktiken der Subjektivierung 1 (Bielefeld: transcript, 2013), 17-18. ${ }^{28}$ The Etymologies of Isidore of Seville, Stephen A. Barney, W. J. Lewis, J. A. Beach and Oliver Berghof (New York: Cambridge University Press, 2006), 67.
} 
Just as today, we would not need to hear that "I went for a drive in a car" - the first part of the sentence would suffice to make the story understandable to us. In consequence, not every situation where a horse was present was described by mentioning the horse. If a horse is mentioned, there must have been some reason for the author to do so. Horses in historiography, therefore, usually serve a narratological purpose and pose as a narrative element.

We need to differentiate, however, between those accounts in which the horses can be seen as actual historical agents and those where they are used as narrative devices, in which case they are small elements of the text's design that either advance the plot or pose as a stylistic element underlining the story. And, of course, the line between these categories is blurred. Depictions of horses unseating their riders - examples of which will be discussed in detail in the following sections - can either be stylistic devices to underline the gravity of the situation or they can be actual historical accounts of people who got hurt while riding. For us as historians, it is virtually impossible to determine with certainty whether we are dealing with a "true" depiction or a "narrative" depiction. (Which, of course, are not exclusive: The fact that an author chose to include a horse's action in their depiction to shape or style the narration does not mean that it did not happen this way.) Luckily, the question of truth is secondary in reconstructing the historical horse agency from historiographical texts. By addressing different passages individually and observing the narrative structures carefully, the historical core of horse agency can be extracted even from those passages where horses serve as a stylistic device.

Why a horse was included in the story can be established by asking, "Does the (hi)story need a horse here?" Depending on the answer to this question, the horse can be interpreted as a historical subject, as a plot device or as a stylistic device - these labels, of course, are not mutually exclusive. They pose different possibilities of reconstructing animal agency, yet a similar approach is needed for all historiographical accounts: having analysed the narrative structures and the general understanding that the narration expects from its readers, the methods of praxeology can be used to reconstruct how horses and horses' bodies shaped the human world. The following sections will explain the ways in which this is possible.

\section{A. Horses as historical subjects}

Horses are seldom mentioned as historical agents who actually had an impact on history that made the story worth preserving for posterity. These are the instances in which we simply cannot claim that the horse was optional to the narration.

One example of this can be found in Ekkehard IV's continuation of the Casus Sancti Galli. These accounts, dating to the tenth century, recount the history of the abbey of St. Gall and, correspondingly, its abbots. Purchart I. was St. Gall's abbot from 958 to 971. Ekkehard's account in the Casuum Sancti Galli continuatio tells us that he liked horses - which also brought his career to an end:

Misitque post dies istos dux ipsa Purchardo nostro, cognato videlicet et amabili suo, ambulatorem valde decibilem et alacrem, ut animum suum lesum et ipsa leniret. Audivit enim eum delicatis equis delectari nimium, sed et, ne pro se pigeret quidem orare. Richunbach invento equus praesentatur laetanter se continens; quem ille continuo amore tantae datricis sellari sibi iubens, abiturus ascendit. At equus exaltanter eum gestans, in postem valvarum curtis hominem teneritudinis, ingeniti tamen ardoris et alacritatis, impegit, et femur ei disiungens, vertibulo coxae evulsit; qua plaga cum per Notkerum pro posse sanaretur, postea tamen absque geminis sustentaculis ingredi non potuit. Et cum talia diu sit passus, Richero iam dicto, curtis suae camerario, homini pro virtutibus vix comparando, 
Ekkehardi decani iam senescentis ut ageret consiliis, et abbatiam pro se regeret, communi fratrum iniunxit consensu.

[And after these days, the duchess herself sent to our Purchart, clearly akin and amiable to her, a very neat and brisk palfrey, to appease his upset mind - because she had heard that he very much enjoyed fine horses and that he wouldn't be reluctant to pray for her, as well. Having arrived in Rickenbach, the horse presented itself restrained and merry. In such great admiration for the donor, he (= Purchart) commanded to have it saddled for him in order to depart at once. However, the horse carried him exuberantly and pushed this man of tenderness, yet of innate heat and eagerness, against the post of a gate and dislodged his femur bone. This injury was treated by Notker as well as he could, but afterwards he (Purchart) could only walk with two canes. And having suffered from this for such a long time, he imposed on the aforementioned Richerus, his chamberlain, a man hardly comparable in his virtues, to act on the advice of the already aging decan Ekkehard and manage the abbey for him, with the consent of the community's brothers. $]^{29}$

In this passage, we see a horse that, by pushing its rider against a post, causes an injury that finally leads to a change of leadership in the abbey of St. Gall. Even if the horse in this case may also be seen as a stylistic or a plot device - therefore, a narrative component - the element of historical agency is much stronger in the horse in this passage than its potential as a narrative device. It does not simply fit into the plot or underline its style (like a stylistic or plot device might) but alters the plot itself, thus posing as the primary agent of the scene.

A description like this offers the possibility of reconstructing both the individual and the collective agency of early medieval horses - one being narrated in the passage, the other hidden behind the text. Looking directly at what the source tells us, we find a horse that acts - in this case, against its rider - thus exerting agency. Speaking in Howell's categories, we find antagonistic agency - the horse breaking the normal behaviour of a mount, displaying deviation or improvisation - which is, at the same time, ascribed agency: Ekkehard acknowledged the possibility of a horse hurting its rider (and in this case, he traces it back to the horse's character), thus ascribing a certain degree of agency which, here, is expressed in the antagonistic act of pushing Purchart against a post.

However, this is not all that can be found out about early medieval riding horses and their agency from a passage like this. Taking a look at the narrative design of this passage, it becomes clear what the audience must have known and thus expected when reading the text. Narrations only work if the author knows their audience. Every narrative or stylistic device aims at the contemporary discourse and the previous knowledge of the reader: The audience cannot be surprised by the appearance of a talking horse if they do not know that horses do not talk. By examining the text carefully, these expectations of the audience can be reconstructed.

In this instance, Ekkehard deems it necessary to mention that the horse was carrying Purchart in an exuberant way, clearly blaming the horse's temper for Purchart's accident. Interestingly enough, Purchart's predecessor, Ekkehard I, also suffered an injury from a riding accident that ultimately forced him to step down. Unlike Purchart's horse, however, his mount slipped on ice and he fell off; no indication of the horse being responsible for the

${ }^{29}$ Ekkehard IV, "Casuum Sancti Galli. Continuatio. I," in Scriptores rerum Sangallensium. Annales, chronica et historia aevi Carolini, ed. Georg Heinrich Pertz. Monumenta Germaniae historica. Scriptores 2 (Hannover: Hahn, 1829), 126. Translation my own. 
accident was given. ${ }^{30}$ In Purchart's case, Ekkehard gives no indication that it was an accident or the rider's fault but leaves the impression that it was inappropriate behaviour by the horse. ${ }^{31}$ He does this to give the reader the context of the incident which shows us as historians that, while horses were everyday mounts, carrying the rider "exuberantly" was not something they were expected to do.

This element of deviation that Ekkehard integrates into his text points to the fact that there was an established way in which horses were to carry their riders - not an exuberant way, blatantly - that the reader must have known about. This collective form of agency would usually be expressed in horses adjusting to the needs of humans, performing those movements that were asked for by the riders and thus enabling a system in which people could rely on regularly riding their mounts.

This passage draws a picture of one horse that used its bodily agency to break the usual conduct of horses - but at the same time, this passage points to a vast group of early medieval horses collectively exerting the practices needed for the humans to successfully ride them. Hence, the rare historiographic accounts where horses actually forward the story and are shown as historical agents offer us a unique insight into the way in which individual horses could exert agency to change their environment (thus impacting humans), but also point to the larger picture of horse agency in general. Therefore, passages like this should never be read as singular occurrences without context, but should always be embedded in the general understandings and concepts of horses in their time.

\section{B. Horses as stylistic or plot devices}

Other passages where the horse is not needed for the story to unfold seldom offer the opportunity of reconstructing individual, situational horse agency. They should, however, not be disregarded when looking for the concept of horse agency as a whole. Occurrences of horses that do not bring the plot forward provide the reader with (more or less plot-relevant) context - they help the reader understand what the story is supposed to be about. Of course, this does not mean that horses did not actually do the things they do in the sources - it only means that the author (consciously or subconsciously) chose to add these details to underline certain aspects of the story - but even if that were the case, the passages would still help us paint a picture of early medieval horses.

Horses that are not necessarily needed for the plot can appear in a variety of situations. Sometimes they are described just as objects, like horses that were stolen during a conquest. Sometimes they do act but without being crucial for the storyline - which we will get back to in the second half of this section. And sometimes they appear as parts of human action. One example of the latter case is the trope of people getting on their horse and riding away which can be found quite frequently in early medieval historiography. It will hereafter be examined in three examples of horses that are mere stylistic devices but can still help us understand early medieval horse history a little better.

\footnotetext{
${ }^{30}$ Ekkehard, "Casuum Sancti Galli," 119.

31 Whether or not the audience would have expected Purchart as a skilled rider to be able to judge the horse's mood cannot be determined with certainty. The mentioning of Purchart's teneritudo (tenderness) might be a hint that he lacked the skill to control the horse in its mood swings or simply a judgement of his character. Yet the turning point of the story is the horse that changes its behaviour and carries the rider in the "wrong" fashion. Even if Purchart were (at least partly) to blame, this would still allow us to reconstruct the medieval audience's expectation: That the horse should be obedient and not carry the rider too exaltedly.
} 
Two of these hints can be found Gregory of Tours' Decem libri historiarum, often simply titled as Histories, which date to the late sixth century and offer a unique insight into the late antique and early medieval European history. Gregory's narrative style is characterised by a vivid storytelling, often employing small elements - objects, animals, gestures - to underline the dramatic moment. ${ }^{32}$ The mentions of horses that can be found in the Histories are very short and, if one is not specifically looking for them, so subtle that they can easily be overlooked.

In book III of the Histories the two Merovingian kings Childebert and Chlothar conspire to kill their deceased brother's children whom they fear the queen (their mother) might put on the throne. More specifically, Chlothar comes to Paris and after the two have deceived the queen into surrendering the two out of three present children to them, Chlothar ruthlessly kills them, while Childebert, having second thoughts and feeling sorry for the children, even tries to stop him. However, Chlothar finishes the deed showing no mercy and leaves town:

"Quibus interfectis, Chlothacharius, ascensis equitibus, abscessit, parvi pendens de interfectione nepotum; sed et Childeberthus in suburbana concessit."

[Having killed them, Chlothachar mounted the horse(s) and left, hardly thinking about his killing of his nephews; and Childebert left to the suburbia. $]^{33}$

The horse in this passage is hardly noticeable, but the choice of words is very interesting: Instead of just using "abscessit" to describe Chlothar leaving, Gregory chooses to include the specification that Chlothar leaves on horseback. Interpreting the horse as a mere status symbol, in this context, makes no sense as the scene revolves around kings, and the reader would not need this detail to understand which status they have - especially not in this situation which revolves around a dramatic murder scene. Mentioning that the king rode off might, instead, be an indication of Chlothar's indifference: if riding was a normal thing, him riding off in this sequence would mean that he just kept doing what he would usually do (in contrast to walking home, which would have been something out of the ordinary). However, this theory cannot go beyond speculation. In comparing this sequence to other similar instances, it quickly becomes clear that Chlothar was not the only one to get on his horse and ride off like this.

In book IX of the Histories, we encounter a bishop who does the same after rejecting a queen's plea. Saint Radegund had, with the king's blessing, sent clerics to collect some relics for her monastery, and upon their return, the queen asked the local bishop to festively place them where they belong:

"Quibus delatis, petiit regina episcopum, ut cum honore debito grandique psallentio in monastyrium locarentur. Sed ille dispiciens suggestionem eius, ascensis aequitibus, villae se contulit."

\footnotetext{
32 A detailed analysis of Gregory's style can be found in Joaquín Martínez Pizarro, "Gregory of Tours and the Literary Imagination: Genre, Narrative Style, Sources, and Models in the Histories," in $A$ Companion to Gregory of Tours, ed. Alexander Callander Murray. Brill's Companions to the Christian Tradition 63 (Leiden/Boston: Brill, 2015), 342-351.

${ }^{33}$ Gregory of Tours, Libri Historiarum X, ed. Bruno Krusch and Wilhelm Levison. Scriptores rerum merovingicarum 1,1 (Hannover: Hahn, 1951), 119. Translation my own.
} 
[When they were brought, the queen asked the bishop to lay them down in the monastery with due honour and great singing. But he, declining her suggestion, mounted the horse(s) and returned to his manor.] ${ }^{34}$

In consequence, the queen gets the king involved and makes him order a different bishop to do what the original (local) bishop had refused to do. This story is not about horses, and the story does not need the bishop to ride home - so why mention them?

In both of these passages, someone leaves - and goes far away. Mounting a horse, accordingly, is an act of starting a journey that will take you somewhere completely different. Gregory uses this as a signal to his readers to show: this person is leaving the scene and probably not coming back (any time soon, at least).

A very interesting example of this trope can be found in the Annales Vedastini, the annals of the abbey of St. Vaast in Arras which were written around the year 900 - roughly three hundred years after Gregory wrote his Histories. At the very end of the book, we read about Robert (who, two decades later, would become king Robert I of West Francia). He was a powerful noble who had supported his brother (Odo of France, the king of West Francia) in his fight against Charles the Simple. In this account, however, we meet him after his brother's death at (now king) Charles' court where he is trying to establish a similarly powerful position - in which he does not succeed but is surpassed by Richard, whom Charles favours. ${ }^{35}$ In this scene, he is being offended and, like the characters in Gregory's Histories, leaves on horseback:

"Unde contigit quadam die, ut Manasses, quidam ex fidelibus Richardi, cum rege loquens quae illi non conveniebat de Rothberto locutus est. Quod ubi Rothberto nuntiatum est, ascenso equo rediit in sua, atque ita omnes discordantes sine ullo effectu reversi sunt [unusquisque in sua]."

[One day it happened that Manasses, one of Richard's abiders, while talking to the king, spoke of Robert in a way that was not agreeable to him. As this was brought to Robert's attention, he mounted his horse and returned home; and thus, all those in disagreement returned without any achievement (each one to their home). $]^{36}$

Just like in the passages cited before, Robert, too, gets on his horse and rides off. However, the notion that he does so because he was angered gives the depiction a slightly different atmosphere. ${ }^{37}$ Since this is the last sentence of the Annales Vedastini, we have no account of what happened immediately afterwards, but one thing becomes perfectly clear: Robert leaves the scene irrevocably. This scene is a medieval version of slamming the door on your way out.

These are just some examples of early medieval historiography using horses to show that long distances had to be overcome. The fact that this trope was used in the sixth century as well as in the tenth may not be surprising, given the fact that written texts were always influenced by older texts and considering that horses were a major means of transport

\footnotetext{
${ }^{34}$ Gregory of Tours, Libri Historiarum X, 464. Translation my own.

${ }^{35}$ Horst Lößlein, Royal Power in the Late Carolingian Age. Charles III the Simple and His Predecessors (Cologne: Modern Academic Publishing, 2019), 154-156, gives an overview of the situation.

36 Anonymus, “Annales Vedastini a. 874 (873) - 899 (900)," in Annales Xantenses et Annales Vedastini, ed. B. de Simson. Scriptores rerum Germanicarum in usum scholarum separatim editi 12 (Hannover: Hahn, 1909), 82. Translation my own.

${ }^{37}$ Lößlein, Royal Power, 155, adds: “That Manasses dared to insult him was clearly a sign for Robert that, for the time being, his was a lost cause." While this may have played into the narration as a whole, it is not specifically mentioned here, and the dramatic styling of the scene is focussed on Robert's anger.
} 
throughout the entire Middle Ages and beyond. However, it still shows us that readers in the sixth as well as the tenth century understood it.

Passages like these hardly acknowledge the horses mentioned in them as living beings let alone as actors. The animals are mere staffage for their humans and the (hi)story that is written around them. Tropes like these, therefore, do not leave much room for the recognition of horse agency. Nevertheless, there is more to it than the simple fact that horses were a widespread means of transport. It is a record of horses actively shaping the human perception of the world they live in.

In reconstructing the horse agency behind these passages, once again the actions of the horses must be analysed. Judging these accounts from a praxeological perspective may (at first) seem absurd, considering that no animal actions are actually described. But this is where we need to glance behind the text: in order to make the plot work, what would the horses have to do?

Individual horse agency, like the one we have encountered in Abbot Purchart's case, cannot be reconstructed from these kinds of passages that use horses only as narrative devices. Collective horse agency, however, is a category that must be considered in every context where horses are employed to shape a narration: the understandings of the reader always rely on the collective horse agency that they would deem "normal" or "ordinary" and from which they would judge the text. So if - as in the cases discussed here - we can observe that "crossing a great distance" is circumscribed by the term "getting on your horse and leaving," this tells us that horses in the early medieval world were an active part of human transportation. Their cooperation and their agency made it possible for humans to cross long distances, which they would otherwise have crossed differently.

The bodily element of agency, in this example, is a strong one: by employing their force, by adjusting to the needs of the humans they transported, and by doing so continuously, horses as a species enabled humans to rely on them for transportation. If we understand animal agency as an omnipresent concept - the possibility for animals to always change the way they act - we must also acknowledge that it was their agency that made it possible for them to become a metaphor for "travelling a long way." Without the horses exerting the practices needed to successfully cross long distances, they would not have been the primary means of transport - and the very subtle, very short mentions we find in historiography about a person leaving a scene would not be about horses.

In the accounts discussed above, the horse - while providing a certain context for the reader - is not necessary for the narration. In other instances, however, the horse can be both stylistically relevant and also add something to the plot. In cases like these, even if the story does not necessarily require a horse, the horse does add something to the story; it is a plot device. A case like this can be found in Einhard's Vita Karoli Magni, the Life of Charlemagne written in the first half of the ninth century. On one of his military campaigns, Charlemagne encounters a bad omen:

Ipse quoque, cum ultimam in Saxoniam expeditionem contra Godofridum regem Danorum ageret, quadam die, cum ante exortum solis castris egressus iter agere coepisset, vidit repente delapsam caelitus cum ingenti lumine facem a dextra in sinistram per serenum aera transcurrere. Cunctisque hoc signum, quid portenderet, ammirantibus, subito equus, quem sedebat, capite deorsum merso decidit eumque tam graviter ad terram elisit, ut, fibula sagi rupta 
balteoque gladii dissipato, a festinantibus qui aderant ministris exarmatus et sine amiculo levaretur. ${ }^{38}$

[He himself, when he was waging his last campaign [in 810] in Saxony against Godefrid, the king of the Danes, was leaving the camp before dawn one morning, when he saw a brilliant meteor suddenly fall from the sky. It cut across the open sky from right to left. As everyone pondered what this sign meant, the horse on which [Charles] was sitting suddenly fell down headfirst and threw him to the ground with such a bang that the clasp holding his cloak snapped and his sword belt was ripped off. The attendants who were present rushed to his side and lifted him up without his weapons or mantle.] ${ }^{39}$

This story could have been told without a horse - the animal does not essentially alter the course of history in this case, but simply underlines the plot that is already there: an enumeration of several bad signs foreshadowing Charlemagne's death.

The fall from the horse could actually be a historical account. However, since no consequences of the fall are mentioned, it is not very likely that it was written down simply to remember that Charlemagne once fell off his horse - which is something not very uncommon amongst frequent riders. The fall does, however, carry symbolic potential as an omen of death. As such, it might have been remembered by contemporaries for that reason. Whether Charlemagne actually fell off his horse or whether Einhard simply chose this picture to underline the gravity of the situation, cannot be established with certainty. But taking a look at the literary models for this narration underlines its meaning: Einhard's Vita Karoli was highly influenced by antique examples, especially Suetonius' Life of Augustus, which served as an example for Einhard's text. ${ }^{40}$ But comparing Einhard's account of Charlemagne's life to Suetonius' Life of Augustus, it becomes clear that although Einhard adapted the occurrence of omens in the emperor's life, no horses were mentioned in the context of Augustus' presages. ${ }^{41}$ Einhard chose to add the fall and ranked it as one of the omens - which works as a narrative device whether it is a historical or a fictitious account. We encounter, therefore, a horse that is essentially a metaphor.

The question of whether or not we are dealing with a "true" account is of secondary importance. Even if we were to find out that this is an accurate description of Charlemagne falling off his horse, this would hardly further the analysis of historical horse agency. We would simply find that, at one point in time, one horse unseated one king, which does not tell us much about the concept of horse agency per se. Therefore, we need to grasp the concept more openly and examine the general knowledge and understandings amongst the audience that the text addresses.

\footnotetext{
${ }^{38}$ Einhard, Vita Karoli Magni, ed. O. Holder-Egger, Scriptores rerum Germanicarum in usum scholarum ex monumentis germaniae historicis separatis editi 25 (Hannover: Hahn, 1911), 36.

39 Einhard, "Vita Karoli Magni," in Carolingian Civilization. A Reader, trans. Paul Edward Dutton (Toronto: Univ. of Toronto Press, 2009), 46.

${ }^{40}$ A detailed analysis of Einhard's recourse to Suetonius can be found in Jean Meyers, "Éginhard et Suétone. À propos des chapitres 18 à 27 de la Vita Karoli," in Les historiens et le latin medieval, ed. Monique Goullet and Michel Parisse. Publications de la Sorbonne. Série Histoire ancienne et médiévale 63, 129150 (Paris: Éditions de la Sorbonne, 2001), and more recently in Antonia Viscusi, "The Second Life of Suetonius' Vitae Caesarum in Einhard's Vita Karoli: A Case of Montage / Assembly," in Classics transformed, ed. Giancarlo Abbamonte and Craig William Kallendorf. Testi e studi di cultura classica 69 (Pisa: Edizioni ETS, 2018).

${ }^{41}$ Suetonius, Life of Augustus, 95-97.
} 
In order to understand this passage, readers would need to know that horses usually can be kept under control, but that scaring the animals might lead to them buck and unseat their riders. The audience also needs to be aware of the negative connotation of a horse throwing off its rider, since a skilled rider normally keeps control over their horse. Generally, skilled men were portrayed as controlling of their horses - losing control only happened either in accidents or due to important external factors like the omens mentioned here. So, the loss of control underlines that something is very wrong here, and Einhard knew that his readers would understand it that way.

Much like in Abbot Purchart's case, the reconstructed discourse behind the historiographical description points in two directions: towards the agency of an individual, deviant horse, and towards the implied collective agency of horses in general. The fact that this description can, in the narration, be understood as a notable situation, a shock even, that accompanies the occurrence of omens of death implies the collective concept present in the readers' minds of how horses should behave: calmly and compliantly carrying their rider and thus keeping the rider safe. Charlemagne's horse breaks the expected behaviour of an animal, stops exerting the bodily movement - the practices - that make the riding possible and thus hurts its rider.

The account of Charlemagne's horse points to a similar concept of horse agency as the historical account of Abbot Purchart. Even if the horse does not ultimately alter the course of history - unlike Purchart's horse - Einhard still used the same trope that can later be found in Ekkehard's narration. This shows that, in analysing historical horse agency, the focus should not be on the narrative itself, but on the prerequisites for understanding it: what must the readers have known or accepted as given in order to understand this text? Even without knowing whether a depiction is historically accurate, a close examination of the narrative structure of the text can serve to reconstruct the early medieval concept of horse agency and, thus, tell us much more about early medieval horses than the author may have intended to reveal.

\section{Conclusion}

In the early medieval world, horses were everywhere. As a result, historiographical texts only mention them if they can make use of it. The key to deciphering horse agency in historiography, therefore, lies in the reconstruction of the readers' expectations. What the readers knew, or did not know, was a prerequisite for the stylistic shaping of the text and is therefore reflected in the narrative structures of each historiographical account. As the examples in these texts show, simple mentions of horses can therefore point to much larger concepts hidden behind the text.

Moreover, the endeavour to reconstruct animal agency must be looked at from a more holistic perspective. Only focussing on deviations or those passages where - by our human standards - the horse exerts its free will is an anthropocentric approach that limits the view of the historical potential that horses actually had. We must therefore look for agency not only in deviation, but also in cooperation. Combined with the reconstructed discourse of the historiography's audience, we may find a concept of what horses usually did, what was considered normal for them, and from this, evaluate early medieval horse agency as a whole. Considering the praxeological, bodily perspective of agency, we thus find an early medieval world in which the cooperation of horses, their adjustment to human needs and commands and the employment of their bodily power to answer these needs was of vital importance for society. Horses, in compliantly working with humans, have shaped the early medieval human world. Without their agency that was exerted in drawing carts, in carrying riders, and so on, the human world would have been a different one. 
Traces of horse agency can be found in any reference to horses - sometimes blatantly, sometimes hidden behind the actual narration. To paint a complete picture of horse agency, therefore, a broad examination of many different accounts is the most fruitful approach. In summary, it becomes clear that the written sources of the early Middle Ages tell us a lot about horses. But when it comes to historiography, a lot of interesting notions can be found not in what is said, but especially in what is left unsaid.

\section{References}

\section{Primary Sources}

Anonymus. “Annales Vedastini a. 874 (873) - 899 (900).” In Annales Xantenses et Annales Vedastini. Edited by B. de Simson. Scriptores rerum Germanicarum in usum scholarum separatim editi 12, 40-82. Hannover: Hahn, 1909.

Anonymus. "Vita Hludowici imperatoris." In Scriptores rerum Sangallensium. Annales, chronica et historia aevi Carolini. Edited by Georg Heinrich Pertz, Monumenta Germaniae historica. Scriptores 2, 604-648. Hannover: Hahn, 1829.

Aurelius Augustinus. "De Ordine." In Contra Academicos, De beata vita, De ordine, ed. Therese Fuhrer and Simone Adam. Bibliotheca scriptorum Graecorum et Romanorum Teubneriana, 116-184. Berlin/Boston: De Gruyter, 2017.

Aurelius Augustinus. De Ordine. Translated by Silvano Borruso. South Bend, Indiana: St. Augustine's Press, 2007.

Barney, Stephen A., W. J. Lewis, J. A. Beach and Oliver Berghof, ed. and trans. The Etymologies of Isidore of Seville. New York: Cambridge University Press, 2006.

Einhard. Vita Karoli Magni. Edited by O. Holder-Egger. Scriptores rerum Germanicarum in usum scholarum ex monumentis germaniae historicis separatis editi 25. Hannover: Hahn, 1911.

Einhard. "Vita Karoli Magni." In Carolingian Civilization. A Reader. Trans. Paul Edward Dutton, 26-49. Toronto: Univ. of Toronto Press, 2009.

Ekkehard IV. "Casuum Sancti Galli. Continuatio. I." In Scriptores rerum Sangallensium. Annales, chronica et historia aevi Carolini. Edited by Georg Heinrich Pertz, Monumenta Germaniae historica. Scriptores 2, 75-147. Hannover: Hahn, 1829.

Gregory of Tours. Libri Historiarum X. Edited by Bruno Krusch and Wilhelm Levison. Scriptores rerum merovingicarum 1,1. Hannover: Hahn, 1951.

Jonas d'Orléans. Instruction des Laïcs. Tome 1 (Livres I-II,16). Edited and translated by Odile Dubreucq. Sources Chrétiennes 549. Paris: Les Éditions du Cerf, 2012.

Suetonius, Lives of the Caesars, Volume I: Julius. Augustus. Tiberius. Gaius. Caligula. Translated by J. C. Rolfe. Introduction by K. R. Bradley. Loeb Classical Library 31. Cambridge, MA: Harvard University Press, 1998.

\section{Secondary Sources}

Alkemeyer, Thomas, Gunilla Budde and Dagmar Freist. "Einleitung." In Selbst-Bildungen. Soziale und kulturelle Praktiken der Subjektivierung, ed. Thomas Alkemeyer, Gunilla Budde and Dagmar Freist. Praktiken der Subjektivierung 1, 9-32. Bielefeld: transcript, 2013.

Bachrach, Bernard S. "Animals and warfare in early medieval Europe." In L'uomo di fronte al mondo animale nell'alto Medioevo, ed. Centro italiano di studi sull'alto medioevo. Settimane di studio del Centro Italiano di Studi sull'Alto Medioevo 31, S. 707-751, 753-764. Spoleto: Presso la Sede del Centro, 1984.

Bellanger, Silke, Katja Hürlimann and Aline Steinbrecher. "Tiere - eine andere Geschichte" Traverse 15: 3 (2008): 7-16. 
Bourgain, Pascale. "Pratique de l'équitation au Moyen Âge d'après les textes littéraires." In Situ 18 (2012), https://journals.openedition.org/insitu/9721 (accessed February 24, 2021).

Brownrigg, Gail. "Medieval Horse Harness. The Evidence of the Images." In The Horse in Premodern European Culture, ed. Anastasija Ropa and Timothy Dawson. Studies in medieval and early modern culture 70, 55-67. Berlin/Boston: De Gruyter, 2019.

Freist, Dagmar. "1.4 Historische Praxeologie als Mikro-Historie." In Praktiken der Frühen Neuzeit. Akteure - Handlungen - Artefakte, ed. Arndt Brendecke. Frühneuzeit-Impulse 3, 62-77. Köln/Weimar/Wien: Böhlau, 2015.

Howell, Philip. "Animals, agency, and history." In The Routledge Companion to Animal-Human History, ed. Hilda Kean and Philip Howell, 197-221. Boca Raton, FL: Routledge 2018.

Kean, Hilda and Philip Howell, ed. The Routledge Companion to Animal-Human History. Boca Raton, FL: Routledge 2018.

Krüger, Gesine, Aline Steinbrecher and Clemens Wischermann. “Animate History. Zugänge und Konzepte einer Geschichte zwischen Menschen und Tieren.” In Tiere und Geschichte. Konturen einer Animate History, ed. Gesine Krüger, Aline Steinbrecher and Clemens Wischermann, 9-33. Stuttgart: Franz Steiner Verlag 2014.

Lößlein, Horst. Royal Power in the Late Carolingian Age. Charles III the Simple and His Predecessors. Cologne: Modern Academic Publishing, 2019.

Martínez Pizarro, Joaquín. "Gregory of Tours and the Literary Imagination: Genre, Narrative Style, Sources, and Models in the Histories." In A Companion to Gregory of Tours. Edited by Alexander Callander Murray. Brill's Companions to the Christian Tradition 63, 337-374. Leiden/Boston: Brill, 2015.

McFarland, Sarah E. and Ryan Hediger. "Approaching the agency of other animals. An introduction." In Animals and Agency. An Interdisciplinary Exploration, ed. Sarah E. McFarland and Ryan Hediger. Human animal studies 8, 1-20. Leiden/Boston: Brill 2009.

Mengozzi, Chiara, ed. Outside the anthropological machine. Crossing the buman-animal divide and other exit strategies. London/New York: Routledge Taylor \& Francis Group, 2021.

Meyers, Jean. "Éginhard et Suétone. À propos des chapitres 18 à 27 de la Vita Karoli." In Les bistoriens et le latin medieval, ed. Monique Goullet and Michel Parisse. Publications de la Sorbonne. Série Histoire ancienne et médiévale 63, 129-150. Paris: Éditions de la Sorbonne, 2001.

Salisbury, Joyce E. The Beast Within. Animals in the Middle Ages. London: Routledge, 2010.

Schatzki, Theodore. "A Primer on Practices." In Practice-Based Education. Perspectives and Strategies, ed. Joy Higgs, Ronald Barnett, Stephen Billett, Maggie Hutchings, and Franziska Trede. Practice, education, work and society 6, 13-26. Rotterdam/Boston/Taipei: Sense Publishers, 2012.

Scott, Shelly R. "The Racehorse as Protagonist. Agency, Independence, and Improvisation." In Animals and Agency. An Interdisciplinary Exploration, ed. Sarah E. McFarland and Ryan Hediger. Human animal studies 8, 45-65. Leiden/Boston: Brill 2009.

Viscusi, Antonia. "The Second Life of Suetonius' Vitae Caesarum in Einhard's Vita Karoli: A Case of Montage / Assembly." In Classics transformed, ed. Giancarlo Abbamonte and Craig William Kallendorf. Testi e studi di cultura classica 69, 29-36. Pisa: Edizioni ETS, 2018. 